\title{
DISTRIBUTIVE TRADE AND ECONOMIC GROWTH: EU28 EVIDENCE FOR THE PERIOD 2008-2015
}

\author{
Svetlana SOKOLOV MLADENOVIĆ(D) ${ }^{*}$, Igor MLADENOVIĆ \\ Djordje ĆUZOVIĆ 3 \\ ${ }^{1,2}$ Faculty of Economics, University of Niš, Nǐ̌, Serbia \\ ${ }^{3}$ Business School of Economics, Novi Sad, Serbia
}

Received 03 November 2018; accepted 04 March 2019

\begin{abstract}
The purpose of this paper is to appoint the causality between economic activity in the sector of distributive trade and the economic growth of 28 European Union nations. Specifically, it examines the impact of changes in turnover per employee in the distributive trade sector in EU member states on the tangible economic growth rate. The determination to adopt this approach stems from the fact that existing studies mainly explore indirect relationship between economic activities in distributive trade and economic development, with less focus on the direct impact of distributive trade on economic growth. The paper utilizes information for the period from 2008 to 2015. The research relies on multiple regression model, with the Hausman test its robustness. The results indicate that a hike in turnover per employee in the distributive trade sector by 10 euros per year in one EU member state increases its real economic growth rate by $0.15 \%$ in that same year. The significance of the made results is reflected in the fact that the survey takes into account the last economic crisis, and highlights negative effects of final consumption expenditure of general government \% GDP on the tangible economic growth rate in EU member states.
\end{abstract}

Keywords: distributive trade, service sector, retail, wholesale, economic growth, economic development, European Union.

JEL Classification: L80, L81, O49.

\section{Introduction}

Due to intense market globalization and distributive trade internationalization, studies on interdependence between economic growth and distributive trade structure are gaining importance. This is particularly significant given that companies entering foreign markets must in the first place, analyze the social system of distributive trade (retail and wholesale) as comfortably as their overall economic and societal environment. Economic and distributive trade theories view the trading system largely in the context of a wider socioeconomic environment

*Corresponding author. E-mail: svetlana.sokolov@eknfak.ni.ac.rs 
(Berman, 2006). It should be added that economic theorists talk about interdependence between economic development and certain changes in economic construction. In this context, in that respect are the so-called Clark-Fisher hypotheses (Lovreta, Radunović, \& Petković, 1998) on the need to classify all economic sectors into the so-called primary, secondary, and tertiary. Agreeing to these hypotheses, in the post-industrial stage of economic development, the tertiary or service sector, which includes distributive trade, gets into the dominant function. Modern approach to distributive trade points to numerous interactions with economic as well as social growth. This implies that economic development affects distributive trade, but also that distributive trade affects economic growth. It is realistic to anticipate a different distributive trade structure in countries with different degrees of economic growth. Numerous surveys corroborate the high level of correlation between distributive trade structure and the degree of economic development (Olsen \& Granzin, 1990; Levy, Weitz, \& Grewal, 2014). This correlation opens the issue of the impact of distributive trade on economic growth, as the most significant factor of economic evolution, being also the research subject in this composition. This research subject arises from two facts. First, studies exploring the impact of distributive trade on economic growth are scarce. They mainly deal with the impact of distributive trade or retail on other macroeconomic performance indicators, such as productivity and employment, or with the impact of foreign trade on economic growth, with primary focus on one or several economies (Williams, 1997; Schneider, 2005; Hendrik \& Lewer, 2007; Ruhiiga, 2011; Benazić, 2014; Balios, Eriotis, Fragoudaki, \& Giokas, 2015; Di Berardino, D’Ingiullo, \& Sarra, 2017). Second, the European Union institutions emphasize the importance of distributive trade, in particular the retail sector, for the efficient single market and overall economic and societal growth. Caved in the above, the paper analyzes the impact of the distributive trade sector on economic growth of the EU countries in the period from 2008 to 2015. The report is split into three sections: 1) Theoretical aspect of economic growth determinants and importance of distributive trade as an economic sector, 2) Defining the hypotheses, the sample, and the inquiry method, 3) Discussion of research outcomes. Modern econometric models are employed, and a multiple regression model constructed with several dependent variables. To prove the model, Hausman endogeneity test is applied.

\section{Theoretical aspect}

\subsection{Determinants of economic growth in developed market economies}

Economic growth is a relatively new phenomenon. More precisely, a serious rise in production value began in England at the end of the 18th century. Thus, it was being directly interrelated to the effects of the first industrial revolution whose material symbol was a steam powered car. Economic development is the most important indicator of the national economic growth. It is an important assumption of the fundamental task in each national economy, defined in terms of maximally meeting the growing demands of the people using available resources (Cvetanović \& Mladenović, 2015; Borcan, Olsson, \& Putterman, 2018). However, the acceleration of economic growth is an extremely complex process. In a certain way, "economic growth rates determine the economic fate of the country in the long run" (Cvetanović, Filipović, \& Dragutinović, 2015). 
The global economic growth of around two and a half centuries was almost immediately linked to the affirmation of industrial output. Withal, in developed market economies, during the 1980s and 1990s, the share of industry in gross domestic product and the share of industry employees in total employment decreased, bringing the phenomenon of de-industrialization and stronger service sector. The shift of the manufacturing industry decreased the share of industry in newly produced value and use, as easily as the so-called tertiarization of the economic social system and the greater share of services, and, therefore, distributive trade, in gross domestic product (Rocha, 2018; Ozak, 2018). These phenomena must be brought into account when weighing the importance of distributive trade in generating economic growth of developed countries, such as the European Union in the previous period.

Neoclassical and endogenous growth theories share the sentiment that the category of technical change is a key generator of economic development. Nevertheless, they are diametrically differences in the discussion of technological changes as a factor of economic development. Neoclassicists do not deal with origins of technological change. Supporters of endogenous explanations, unlike neoclassicists, tend to know the basic drivers of technical change.

Key drivers of technical changes in endogenous theory are knowledge, research and development (Cinnirella \& Streb, 2017; Delogu, Docquier, \& Machado, 2018). These elements, like standard production factors, create new values. They manifest external effects, i.e. nondecreasing returns of production factors at the mass floor.

Endogenous growth explanations seek, to ascertain, in a better and altered way in comparison with the previous growth theory, the path in which market forces, public policy decisions, and different institutional solutions affect the growth dynamics in single countries (Samuelson \& Nordhaus, 2008). In contrast to previous approaches, endogenous growth theorists seek ways to explain economic growth determinants, which remained unexplained in the neoclassical growth equation. The message of all endogenous economic growth theories is that economic policy makers can influence long-term growth rate. The economic development rate can be unorganized, in particular by the impact of development policy on improved human capital, or, by innovation promotion policies.

The importance of human capital is in focus in one of the approaches of endogenous growth theory. Modern economic systems have recognized the importance of investment in human capital development. This is particularly important in the sense of comprehensive application of scientific solutions in the production process. At the same time it is a precondition of intensive development of new technology, and continuous improvement of organizational patterns and production management methods. Education, accomplishments, and knowledge are the central factors of productivity growth of people and the economy as a whole. Economically developed nations have invested in the development of human capital in the production process (Cvetanović \& Despotović, 2014; Battisti, Del Gatto, \& Parmeter, 2018).

Endogenous growth theory also emphasizes the significance of technological change as a development driver. In this context, the most well-known endogenous growth models are those based on externalities in the sort of spillover effects and growth models based on applied research and development actions. 
An important place in endogenous economic growth models belongs to the research and development actions. The inaugural group of endogenous growth models, includes the Romer's model (Romer, 1989), which also notes the emergence of endogenous growth explanations. In this theoretical account, knowledge accumulation is treated as a by-product of company decisions to invest in physical capital, since capital accumulation indirectly increases the company knowledge stock thanks to the operation of "learning by exercising". Referable to the effects of knowledge distribution, i.e. spillover effects, other companies benefit too, so knowledge keeps its character of the public good. Knowledge transfer to other business entities leads to positive technological externalities, which gets a growing return to these societies. Getting hold of capital available to other companies as given, Romer assumes that the production part in each single company can have a usual neoclassical form. Yet, at the same time, it is presumed that the capital productivity of each single company can arise with the aggregate capital held by other societies. In other words, investment in production stock generates externalities, then all companies taken together do not face diminishing returns. The second group of growth models that emphasizes the importance of technological change includes models based on applied research and development activities, building on some of Schumpeter's ideas. The first endogenous growth model belonging to this group was developed by Romer (1990), followed by Aghion and Howitt (1998), Grossman and Helpman (1994). In endogenous growth models of this group, characterized by monopolistic power, it is basically assumed that there is a separate research sector in the economy, which supplies other sectors with innovation.

The third attack in the (new) endogenous growth theory stresses the importance of institutional factors for economic growth pace in the long run. In other words, a quantitative approach is applied to estimate the impact of key political and institutional factors on economic development. For example, Scully (1988) compares 115 market economies in the period 1960-1980 correlating economic growth dynamics with indicators that express the point of political, civic, and economic freedoms, and establishes that the social system of political institutions has a substantial impact on economic development. More precisely, according to this study, the most dynamic economic development rates are recorded in countries with a developed organization of sound security and individual belongings. The consequences of this and similar research (Kornai, 1992; Rodrik, 2007; Aldashev \& Zanarone, 2017) only strengthen the attitudes of the so-called non-institutional economic theory, whose postulates are implemented in this third approach of (new) endogenous economic growth theories.

There is no uncertainty that the application of fresh technology, human capital development, and institutional factors will be a significant causal factor of future economic growth in advanced market economies. At the same time, distributive trade (retail and wholesale) has over the past several decades been a polygon for the concentration of modern technical solutions and lasting advance of knowledge and skills implemented among employees in this economic sector. In addition, distributive trade internationalization has occurred in precisely the countries with adequately regulated institutions. All this contributes to a consistent conclusion that distributive trade sector should bear a substantial impact on the economic growth pace in modern market economies. The achievements of new (endogenous) economic growth theories have been an inspiration to look at empirical and theoretical works that examine the link between economic growth and distributive trade. 


\subsection{Distributive trade and economic growth}

In modern economic conditions, economic growth is one of the major economic policy goals. In other words, economic growth rate is progressively viewed as an indicator of efficient economic policy. In increase, high economic growth rates suggest that the economy has greatly employment opportunities, as well as more goods and services available to occupants of that state. It is logical that economic policy makers are more interested in those sectors that generate higher growth rates. In the past, they concentrated in the industrial sector. In the nineteen-sixties, many countries began to turn to the service sector, with deindustrialization coming to the fore (Blackaby, 1978), which has already been talked about.

On that point are numerous works that directly to the connection between the service sector and economic development. Recent studies differently analyze the Schumpeter aspect of long-term economic changes and the importance of innovation as the foundation for economic growth and development (Lundquist, Olander, \& Henning, 2008). They also indicate to the transforming economic structure in different countries and the complementarity between products and services and helps in generating economic growth, with the correlation between them varies between countries and parts within an individual country (Lundquist, Olander, \& Henning, 2005, Williams \& Horondic, 2018; Kedir, Williams, \& Altinay, 2018). Inquiry proves that greater focus on services is due to the fact that service providers perform increasingly important functions in developed market economies. The growing service sector was also one of the most visible empirical trends at the remainder of the last century (Khayum, 1995; Warland \& Mayer, 2017; Ghavidel \& Sheshkalany, 2017). What is more, this trend continues in this century. The outcomes of numerous studies confirm this. Thus, Beyers (2005) examines the substantial development of the IT sector in the United States during the 1990s, highlighting the share of the service sector in employment and economic growth, much higher than in former years. His analyses speak about the increasing employment within the ICT sector, marketing, music, and style. A similar movement is put down in the United Kingdom, where these sectors increased employment by $35 \%$ in the period from 1994 to 2001 (Bryson, Daniels, \& Warf, 2004; Daniels \& Bryson, 2005; Lundquist, Olander, \& Henning, 2006). In recent years, studies focus on the service sector on emerging markets. Thus, Clemes, $\mathrm{Hu}$, and $\mathrm{Li}$ (2016) analyze the expansion of the service sector in China and the impact on GDP per capita. They develop empirical models for assessing the relationship between the service sector in China and economic growth variables. The results support the hypothesis that export growth and government spending have a major consequence of the increase of value added in the service sector, which, on the other hand, possesses a positive impact on economic growth rates. Nevertheless, it is concerning that this survey finds no positive consequence of the service sector spill over on production growth, and frailty versa.

Distributive trade (retail and wholesale) is a service sector that has become an significance economic segment in late years. Distributive trade includes the sum of all distributive trade forms, from the purchase of goods from the manufacturer to the deliverance of goods to the consumer (Benazić, 2014). In addition, distributive trade includes retail and wholesale, and, according to the Statistical classification of economic activities in the European Community (Eurostat, 2008), belongs to the sector classified in the group "G". According to Kotler, 
Keller, and Martinović (2014), wholesale includes all actions directed at selling products and services to business entities that do not utilize them for their own needs, while retail includes all actions of trading merchandise and services straight to final consumers for their personal, non-business utilization. According to Dibb, Simkin, Pride, and Ferrell (1991), retail includes all proceedings in which the consumer intends to eat the product through personal, family, or household exercise. End consumers have the purpose of retail consumers, while the retailer is a system that purchases products to sell to end consumers.

The European Union institutions emphasize the significance of distributive trade, in particular the retail sector, for the efficient single market and overall economic and societal development. The European Commission paper (2013) points out that the retail sector is a driver of growth, competitiveness, and exercise, and induces a central role in reaching the European Union strategy goals by 2020. In this way, the retail sector is the "pillar" of the European economy, since its services are essential in the modern economy of the European Union and have an important integrative role on the internal European market, since they provide consumers with products from all member countries.

The latest European Commission document (2018) points out that the dynamic and competitive retail sector is important for consumers, commercial enterprises, and the overall economy of the European Union. A great number of businesses and jobs, with their contribution to value-added creation, hit retail a key sector in fostering long-term economic development. According to official statistics, retail is the largest sector in the non-financial segment of the European Union, in terms of number of companies and employees, creating $4.5 \%$ of the European value added and providing $8.6 \%$ of all jobs (Eurostat, 2018). With the intensive growth of consumer demands and technical advancement, the retail sector is quickly transforming and represents a catalyst for invention and productivity. Households in the European Union spend up to one third of their budget on products distributed by retailers. Retail prices, choice, and product quality affect the character of aliveness in the EU. Approximately 3.6 million retailers interact with societies from other sectors, such as wholesale, manufacturing, logistics, shipping, and other societies. Better retail operations in this manner can result in positive spillover effects on the total economy. The EU's single market has approximately 500 million potential retail consumers. Still, this takes a prosperous business and regulatory framework that fits the needs of traders and helps them react to the challenges they face globally.

European Union bodies are always trying fresh solutions to further improve the single market and reach a higher level of competitiveness of the economy and distributive trade. They track innovation and improvement in the distributive trade sector, in particular retail, present solutions, and encourage distributive trade development as an integrative market determinant. The principal activities concentrate on enhancing awareness about the significance of distributive trade and retail, then on education, making a prosperous climate for the introduction of innovation, and so on.

In summation to the practical activities of the European institutions, numerous studies suggest that modern and efficient distributive trade is important for improving the competitiveness of the economy, as well as development in the overall productivity of economic organizations. Several surveys and papers mainly examine the link between distributive 
trade and productivity growth (Di Berardino et al., 2017). In behaving thus, they examine the nexus at the stratum of a particular region or economic system. Thus, Cuadrado-Roura (2013) concludes that large urban centers and areas tend to increase demand, thus attracting services in distributive trade, while medium-sized urban centers and regions attract a slightly smaller number of service providers, and, therefore, trading companies. The study by Capello and Fratesi (2013) is likewise interesting. Examining the European regions in the period from 1997 to 2007, they find differences in sectoral growth rates, depending on the globalization process. They record growth of global trading companies by $2 \%$ per year, and local company growth by $0.5 \%$ per year. The report examines the relationship between distributive trade growth and globalization. Then, Garcilazo, Mouradian, and Oliveira-Martins (2013), analyzing the sample of the OECD region, find that productivity in the inspection and repair sector is on average similar to the overall productivity of the economic system. Their research shows productivity growth in retail and wholesale of $26 \%$ and $33 \%$ of average productivity. Likewise, the outcomes of the analysis show the existence of potential for distributive trade productivity growth in underdeveloped areas and their greater dependence on regional and local labor markets.

Williams (1997) points out the significance of distributive trade, especially retail, to conclude that retail is not a "parasitic" activity and that it leads to economic growth. In short, this research shows that the retail sector needs to be advanced in economic conditions, since retail chains generate a function of external income. His research focuses on Great Britain. Further works along the significance of distributive trade and retail focus mainly on the economy of one land, region, or several countries. For example, Ruhiiga (2011) examines the development of retail and wholesale in the region of rural South Africa. The outcomes indicate that it is improbable that the retail and wholesale sector will take on a starring part in the local economies of rural South Africa in the future, which is a restriction to the perspective of long-term economic growth. The author suggests the promotion of the distributive trade sector through innovation and additional engagement of state institutions. Ling (2013) also highlights the regional aspect of the significance of distributive trade and retail sector. This report supports the solid relationship between innovation in the retail sector and structural alterations in the distributive trade sector, on the unitary hand, and productivity growth of this sector and economic growth, which is very important for Malaysia as a developing nation. In behaving so, it is remarked that the Malaysian office is not a lonely case because similar tendencies can be established in other developing nations. Furthermore, Balios et al. (2015) also take regional approach to distributive trade, studying the economic efficiency of the Greek retail sector with a focus on small and medium-sized enterprises, before and after the crisis that started in 2008. With the diligence of the Data Envelopment Analysis (DEA), they break down the impact on the efficiency of retail companies in GDP growth, before and after the recession, in different areas. The answers show that companies on the islands are more effective than those on land, and that company in the cities is least efficient. Additionally, companies with stable business during the recession period continue positive business, whereby they should increase the percentage of their own capital. Moreno and Carrasco (2015) establish a similar analysis of the efficiency of the retail sector, falling out the case of Spain. The report examines the efficiency of the retail sector in Spain. The out- 
comes indicate that the retail company size, its age, and market are the most significant causal factors of company efficiency in the period studied, with significant variances between the regions to which they go. A recent survey (Di Berardino et al., 2017) examines the relationship between distributive trade sectors (retail and wholesale) and productivity development in Italian provinces. With the role of the panel data, in the period from 2000 to 2013, the influence of employment growth in distributive trade on productivity growth is examined. The answers show that distributive trade has a strong positive impact on productivity growth.

It is observed that previous studies pay less attention to the relationship between distributive trade and economic development in a larger number of states, such as the European Union. Studies analyzing the shock of certain distributive trade (retail and wholesale) development, determinants of economic development of the European Union member countries as a whole are scarce. All previous papers focus on individual states or areas. For this reason, this work analyzes the impact of economic activities in the distributive trade sector on economic growth in all EU member countries. For this design, turnover per employee in the distributive trade sector in each EU member country will be practiced as an indicator of economic activity in distributive trade, and economic growth pace will be quantified by real GDP growth rate in analyzed economies and a determined time interval.

\section{Research methodology}

\subsection{Hypotheses, data, and methodology}

Taking into account the outcomes of theoretical and empirical research, the research question relates to whether the development of economic activities in the distributive trade sector in the EU28 has an equal contribution to the dynamics of economic development? In conformity with this research question, null and alternative hypotheses have been made. The null hypothesis is - H0: The growth of economic activities in the distributive trade sector in the EU28 has no positive impact on the dynamics of economic growth. Alternative hypothesis H1: The growth of economic activities in the distributive trade sector in the EU28 has a positive impact on the dynamics of economic growth. To give an answer to this research question, it is necessary to define the timeframe of analysis, select the research methods and parameters to be observed. The purpose is to observe the EU28 countries in the period from 2008 to 2015. This eight-year period is sufficiently long to provide for valid observation results, and also represents a period in which there was an enlargement and contraction of the tier of economic activity, so that it brings into account the reality of the cyclical nature of economic action.

As regards the research method, multiple regression is preferred. Multiple linear regression is the most usual kind of linear regression analysis. As a predictive analysis, the multiple linear regression is applied to explicate the relationship between one continuous dependent variable and two or more independent variables. Parameters to be honored during the defined time period have been adapted to the research question. In this respect, the dynamics of economic action are examined utilizing the actual GDP growth pace, as a significant aggregate macroeconomic indicator. This value will, in this study, stand for the dependent variable. 
On the other hand, the independent variable will be the one that symbolizes the economic activity in the distributive trade sector in the selected states. This is undoubtedly turnover per employee in euro, which is consistent with the statistical classification of economic activities in the European Union (NACE - Nomenclature statistique des activités économiques dans la Communauté européenne), its different versions being used since 1970. For practical reasons (in order to avoid skewed data) we had log-transformed turnover per employee as independent variable. Besides the dependent and independent variables, multiple regression also requires the control variables. This subject concentrates on the two such variables, which, without any doubt, have an impact on the dynamics of economic action, namely the actual economic growth pace.

The first control variable is final consumption expenditure of general government \% GDP. The pick of this control variable is the consequence of the fact that final consumption expenditure of general regime is closely correlated with economic activities in the distributive trade sector. At the same time, final consumption expenditure of general government during the observation period was the issue of critics of unsustainable government budget deficits in EU countries and main constraint to further economic development. The second control variable is the financial crisis that took place in the period studied, whose omission would reduce the validity of the findings in this survey. The fiscal crisis is manufactured as an artificial binary variable (dummy). 2008 and 2009 are marked as the crisis years. In these years, in the nations studied, the dummy variable value is 1 , while in other years, when there was no financial crisis, the value of this variable is 0 . All information is taken from Eurostat and presented in the supplementary file. We stress that we concentrate on the fiscal crisis as a variable. This is because in other years same countries had negative real economic growth rate, but this is the outcome of the public finance crisis and external debt crisis.

As already mentioned, multiple regression model will be used to analyze the 28 EU countries, hence the turn of lands shall be given as $i=1, \ldots 28$. These states are followed over a period of 8 years, $t=1, \ldots 8$. The regression model is as follows:

$$
y_{i t}=\alpha+x_{i t}^{\prime} \beta+c_{i}+u_{i t},
$$

where $y_{i t}$ is the dependent variable, $\alpha$ is the constant, $x_{i t}^{\prime}$ is K-dimensional row vector which is related to the independence and control variables, $\beta$ is a $\mathrm{K}$-dimensional column vector of parameters with the independence and control variables, $c_{i}$ is the effect ofthe specificity of the observed economy and $u_{i t}$ represents the residual. If the number of yearsanalyzed is 8 , then $T=8$, so all observations for each country are summarized by the following matrix:

Dependent variable $y_{i}$ is presented by using the following matrix:

$$
y_{i}=\left[\begin{array}{c}
y_{i 1} \\
\dot{y_{i 5}} \\
\dot{y_{i 8}}
\end{array}\right], \quad y_{i}=[8 \times 1] .
$$


For independent and control variables $X_{i}$, the matrix is as follows:

$$
X_{i}=\left[\begin{array}{c}
x_{i 1}^{\prime} \\
\cdot \\
x_{i 5}^{\prime} \\
\cdot \\
x_{i 8}^{\prime}
\end{array}\right], \quad X_{i}=[8 \times 3]
$$

as the focus of analysis is on 3 variables (one independent and two control) in the regression model, so the number of $\mathrm{K}$ dimensions in this case is 3 .

The matrix of residual in the analyzed model is:

$$
u_{i}=\left[\begin{array}{c}
u_{i 1} \\
\dot{u_{i 5}} \\
\dot{u_{i 8}}
\end{array}\right], \quad u_{i}=[8 \times 1] .
$$

If the last of the countries analyzed $i$ is marked by $N, a(N=28)$ and the last year analyzed $t$ is marked by $T, a(T=8)$, then NT will mark all observations in all countries over the entire observation period, namely: dependent variable $y$ is presented in the form of the matrix

$$
y=\left[\begin{array}{c}
y_{1} \\
\dot{y} \\
\dot{y_{i}} \\
\dot{y_{28}}
\end{array}\right], \text { of order } y=[N T \times 1]
$$

Independent and control variables $\mathrm{X}$ are presented in the form of the matrix:

$$
X=\left[\begin{array}{c}
X_{1} \\
\dot{X_{i}} \\
\dot{X_{28}}
\end{array}\right], \quad \text { of order } X=[N T \times K]
$$

Residual $u_{i}$ is presented in the form of the matrix:

$$
u=\left[\begin{array}{c}
u_{1} \\
\dot{u_{3}} \\
\dot{u_{8}}
\end{array}\right] \text {, of order } u=[8 \times 1]
$$

The question that arises in the model shown in equation (1) is whether there is correlation between the residual $u_{i t}$ (containing the specific effect of the observed country $c_{i}$ ), 
on one side, and independent and control variables, on the other side. Speaking in mathematical terms, the question is whether $E=\left(u_{i t} \mid X_{i}, c_{i}\right)=0$, when there is no correlation, or $E=\left(u_{i t} \mid X_{i}, c_{i}\right) \neq 0$, when there is a correlation.

In theoretical terms, this is a multiple regression model with random or fixed effects (Schmidheiny, 2013). Multiple random-effect model in this exceptional case would mean that the specificity of the observed country marked by sea is not correlated with the autonomous and control variables, and that it changes over time independently of the state. This is an extremely rigorous assumption that is very rarely used by economists in such inquiry. Multiple fixed-effect model implies that the specificity of the observed country can be correlated with the autonomous and control variables, and that it does not vary with the passing of time, i.e. that it reflects the specifics of business and system environment, characteristic of each nation. This premise is much morenaturalisticand more prevalent in macroeconomic research. In the present work, multiple fixed-effect model has been selected, with the carrying out of adequate statistical tests to look into its validity in relation to the random-effect model.

\subsection{Results and discussion}

The analysis starts by descriptive statistics, in order to assess the connection between the analyzed variables. Results of descriptive statistics are presented in Table 1.

Table 1. Descriptive statistics and names of variables (source: authors' calculations)

\begin{tabular}{|l|c|c|c|c|c|}
\hline \multicolumn{1}{|c|}{ Variables } & Obs. & Mean & Std. Dev. & Min & Max \\
\hline Real GDP growth rate & 224 & 0.0057 & 0.0395 & -0.177 & 0.256 \\
\hline $\begin{array}{l}\text { LOG Turnover per } \\
\text { employee }\end{array}$ & 223 & 12.555 & .622 & 11.388 & 14.596 \\
\hline $\begin{array}{l}\text { Final consumption } \\
\text { expenditure of general } \\
\text { government\% GDP }\end{array}$ & 224 & 0.2043 & 0.0329 & 0.123 & 0.298 \\
\hline Dummy & 224 & 0.2500 & 0.4339 & 0 & 1 \\
\hline
\end{tabular}

The consequences indicate that, among the 28 nations surveyed in the eight-year period, there is a significant standard deviation of the actual economic growth rate, several times the median value. On the other hand, the case with independent variable is opposite. This fact has been a further research challenge to demonstrate the importance of productivity in the distributive trade sector for economic growth in the countries analyzed. What succeeds is the demonstration of the correlation matrix between dependent, independent, and control variables.

Solutions in Table 2 show that among the variables there is no significant correlation, which is exceedingly important for the application of multiple regression example. It is interesting that between the subject and independent variables there is a very weak correlation, which further complicates the research question, but also supports the right glide path in 
selecting the research method. The consequences of the selected research method, multiple regression with fixed effects, are presented in the next Table (3).

Table 2. Correlation matrix between independent variable and predictors (source: authors' calculations)

\begin{tabular}{|l|c|c|c|c|}
\hline \multicolumn{1}{|c|}{ Variable } & Real GDP & $\begin{array}{c}\text { Turnover per } \\
\text { employee in } \\
\text { mil. Euro }\end{array}$ & $\begin{array}{c}\text { Final consumption } \\
\text { expenditure of general } \\
\text { government \% GDP }\end{array}$ & Dummy \\
\hline Real GDP growth rate & 1.0000 & & & \\
\hline $\begin{array}{l}\text { LOG Turnover per } \\
\text { employee }\end{array}$ & 0.0912 & 1.0000 & & \\
\hline $\begin{array}{l}\text { Final consumption } \\
\text { expenditure of general } \\
\text { government \% GDP }\end{array}$ & -0.2286 & 0.3713 & 1.0000 & 1.0000 \\
\hline Dummy & -0.4119 & -0.0781 & 0.0885 & \\
\hline
\end{tabular}

Table 3. Multiple regression using fixed effect model (source: authors' calculations)

\begin{tabular}{|c|c|c|c|c|c|c|}
\hline \multicolumn{3}{|c|}{ Fixed-effects (within) regression } & \multicolumn{4}{|c|}{ Number of obs 223} \\
\hline \multicolumn{3}{|l|}{ R-sq: $\quad$ within $=0.4809$} & \multicolumn{4}{|c|}{ Number of groups $=28$} \\
\hline \multicolumn{3}{|l|}{ between $=0.0061$} & \multicolumn{4}{|c|}{ Obs per group: $\min =7$} \\
\hline \multicolumn{3}{|l|}{ overall $=0.0439$} & \multicolumn{4}{|c|}{ avg $=8.0$} \\
\hline & & & \multicolumn{4}{|l|}{$\max =8$} \\
\hline & & & \multicolumn{4}{|c|}{$F(3.192)=59.28$} \\
\hline \multicolumn{3}{|l|}{ corr $\left(\mathrm{u} \_\mathrm{i}, \mathrm{Xb}\right)=-0.9480$} & \multicolumn{4}{|c|}{ Prob $>F=0.0000$} \\
\hline Real GDP growth rate & Coef. & Std. Err. & $\mathrm{t}$ & $\mathrm{P}>|\mathrm{t}|$ & \multicolumn{2}{|c|}{ [99.9\% Conf. Interval] } \\
\hline $\begin{array}{l}\text { LOG Turnover per } \\
\text { employee }\end{array}$ & 0.15 & 0.02 & 6.12 & 0.000 & 0.07 & 0.24 \\
\hline $\begin{array}{l}\text { Final consumption } \\
\text { expenditure of general } \\
\text { government \% GDP }\end{array}$ & -1.05 & 0.19 & -5.32 & 0.000 & -1.71 & -0.39 \\
\hline Dummy & -0.01 & 0.005 & -2.51 & 0.013 & -0.03 & -0.04 \\
\hline _cons & -1.74 & 0.34 & -5.14 & 0.000 & -2.88 & -0.60 \\
\hline sigma_u & 0.08889 & & & & & \\
\hline sigma_e & 0.02882 & & & & & \\
\hline rho & 0.90483 & \multicolumn{4}{|c|}{ (fraction of variation due to $\mathrm{u} \_\mathrm{i}$ ) } & \\
\hline F test that all $\mathrm{u}_{-} \mathrm{i}=0$ : & $(27,192)=$ & & \multicolumn{3}{|c|}{ Prob $>\mathrm{F}=0.0000$} & \\
\hline
\end{tabular}

The outcomes in Table 3 show that independence and control variables in the model are statistically important. F test statistics have an adequate degree of probability, which indicates that all coefficients of the variables are different from zero, and have an impingement 
on the dependent variable (in this case, real economic growth rate). It should as well be mentioned that the correlation between variables (independence and control) and residual is different from zero, in this case -0.9480 . Its negative value shows that the variables were properly introduced into the constructed model. More specifically, if the independence and control variables effectively determine the value of the dependent variable, and so the value of residual (statistical error) is less. Grounded on the above, it can be reasoned that the econometric model is passable, and records:

$$
\begin{aligned}
& (\text { Real GDPgrowth rate })_{i t}=0.15(\text { LOGTurnover per employee })_{i t}- \\
& 1.05(\text { Final consumption expenditure of general government } \% \text { GDP })_{i t}- \\
& 0.01(\text { Dummy })_{i t}-1.74+c_{i}+u_{i t} .
\end{aligned}
$$

The consequences of the example presented in equation 8 points to the conclusion that, by applying ceteris paribus clause (with other circumstances unchanged), if a country in the EU28 in one year increases the turnover per employee in the distributive trade sector by $10 €$, it causes an increment in the actual economic growth rate in that year by $0.15 \%$. The present model is in line with theoretical postulates and the starting hypothesis. The presented model has a coefficient of determination $\mathrm{R}=0.4809$, which means that it is valid in $48.09 \%$ of observations in the EU28 in the period from 2008 to 2015. This has unequivocally confirmed the alternative hypothesis $\mathrm{H} 1$.

In addition to establishing an alternative hypothesis, the constructed econometric model confirms the fact that in the EU countries final consumption expenditure of general government sector can sustain a negative impact on real economic growth pace. More precisely, with the clause ceteris paribus, growth of final consumption expenditure of general government by $1 \%$ of GDP will lead to a decline in the actual economic growth rate by 1.05 percentage points. This is just proof that the increase of the budget deficit could be an extra constraint to the economic development of the EU member countries, especially after the 2008 fiscal crisis.

\subsection{Hausman test for Endogeneity of the Model}

The constructed multiple regression model has set forth from the premise that there is a correlation between the residual $u_{i t}$ (carrying the specific effect on the observed country, $c_{i}$ ), on one side, and the independent and control variables, on the other side. Speaking in mathematical terms, $E=\left(u_{i t} \mid X_{i}, c_{i}\right) \neq 0$. More specifically, multiple regression model with fixed effect has been designed. This implies that the specificities of the observed countries have an endogenous character, i.e. interpreting the inner purpose of actual economic growth rate, and are correlated with the autonomy and control variables. To verify the robustness of this assumption, and, consequently, the constructed econometric model, Hausman test is given. The null hypothesis in this test states that there is no correlation between the residual $u_{i t}$ (carrying the specific effect on the observed country, $c_{i}$ ), on one side, and the independent and control variables, on the other side. In other words, the random - effect model should be habituated. An alternative hypothesis is that the correlation does exist, and that it is a fixed-effective example that is tolerable. For this aim, the random-effect model has been made (Table 4), and the test results are shown in Table 5. 
Table 4. Regression using random effect (source: authors' calculations)

\begin{tabular}{|c|c|c|c|c|c|c|}
\hline \multicolumn{4}{|l|}{ Random-effects GLS regression } & \multicolumn{3}{|c|}{ Number of obs 223} \\
\hline \multicolumn{4}{|l|}{ Group variable: Country } & \multicolumn{3}{|c|}{ Number ofgroups $=28$} \\
\hline \multicolumn{4}{|l|}{ R-sq: $\quad$ within $=0.3241$} & \multicolumn{3}{|c|}{ Obs per group: $\min =7$} \\
\hline \multicolumn{4}{|l|}{ between $=0.0424$} & \multicolumn{3}{|l|}{ avg $=8.0$} \\
\hline \multirow{2}{*}{\multicolumn{4}{|c|}{ overall $=0.2197$}} & \multicolumn{3}{|l|}{$\max =8$} \\
\hline & & & & \multicolumn{3}{|c|}{ Wald chi2 $(3)=76.26$} \\
\hline \multicolumn{4}{|l|}{ corr $\left(\mathrm{u} \_\mathrm{i}, \mathrm{X}, \mathrm{)}=0\right.$ (assumed) } & \multicolumn{3}{|c|}{ Prob $>$ chi $2=0.0000$} \\
\hline Real GDP growth rate & Coef. & Std. Err. & $\mathrm{z}$ & $\mathrm{P}>|\mathrm{z}|$ & \multicolumn{2}{|c|}{$\begin{array}{l}\text { [99.9\% Conf. } \\
\text { Interval] }\end{array}$} \\
\hline LOG Turnover per employee & 0.015 & 0.005 & 2.92 & 0.003 & -0.001 & 0.032 \\
\hline $\begin{array}{l}\text { Final consumption expendi- } \\
\text { ture of general government } \\
\% \text { GDP }\end{array}$ & -0.441 & 0.096 & -4.60 & 0.000 & -0.757 & -0.125 \\
\hline Dummy & -0.032 & 0.005 & -6.25 & 0.000 & -0.050 & -0.015 \\
\hline _cons & -0.090 & 0.062 & -1.44 & 0.150 & -0.296 & 0.116 \\
\hline sigma_u & 0.009801 & & & & & \\
\hline sigma_e & 0.028828 & & & & & \\
\hline rho & 0.103619 & \multicolumn{4}{|c|}{ (fraction of variation due to $\mathrm{u} \_\mathrm{i}$ ) } & \\
\hline
\end{tabular}

Table 5. Hausman test result (source: authors' calculations)

\begin{tabular}{|c|c|c|c|c|}
\hline & \multicolumn{2}{|c|}{ - Coeficients - } & \multirow[b]{2}{*}{$\begin{array}{c}(\mathrm{b}-\mathrm{B}) \\
\text { Difference }\end{array}$} & \multirow[b]{2}{*}{$\begin{array}{c}\left.\text { Sqrt (diag }\left(\mathrm{V} \_b-\mathrm{V} \_B\right)\right) \\
\text { S.E. }\end{array}$} \\
\hline & $\begin{array}{l}\text { (b) } \\
\text { fixed }\end{array}$ & $\begin{array}{c}(\mathrm{B}) \\
\text { random }\end{array}$ & & \\
\hline LOG Turnover per employee & 0.156803 & 0.015480 & 0.141323 & 0.025063 \\
\hline $\begin{array}{l}\text { Final consumption } \\
\text { expenditure of general } \\
\text { government \% GDP }\end{array}$ & -1.050996 & -0.441805 & -0.609190 & 0.172663 \\
\hline Dummy & -0.012971 & -0.032811 & 0.019840 & . \\
\hline \multicolumn{5}{|c|}{$\begin{array}{l}\mathrm{b}=\text { consistent under Ho and Ha; obtained from xtreg } \\
\mathrm{B}=\text { inconsistent under Ha, efficient under Ho;obtained from xtreb } \\
\text { Test: Ho:difference in coefficients not systematic } \\
\text { chi2 }(4)=(\mathrm{b}-\mathrm{B}){ }^{\prime}\left[\left(\mathrm{V}_{-} \mathrm{b}-\mathrm{V} \_\mathrm{B}\right)^{\wedge}(-1)\right](\mathrm{b}-\mathrm{B})=84.17 \\
\text { Prob>chi2 }=0.0000 \\
\left(\mathrm{~V} \_\mathrm{b}-\mathrm{V} \_\mathrm{B} \text { is positive definite }\right)\end{array}$} \\
\hline
\end{tabular}

The resolution of the Hausman test with a probability of virtually $100 \%$ rejects the null hypothesis, based on which the random-effect model is more appropriate. This clearly indicates that the alternative hypothesis is supported. More specifically, there is a correlation between the residual $u_{i t}$ (carrying the specific effect on the observed country, $c_{i}$ ), on one side, and the independent and control variables, on the other side. Speaking in mathematical terms, $E=\left(u_{i t} \mid X_{i}, c_{i}\right) \neq 0$. This means that the constructed multiple regression fixed-effect model is entirely acceptable.

The research carried out clearly suggests that the growth in economic activities in the distributive trade sector has a substantial positive impact along the real GDP growth rate in the EU countries from 2008 to 2015. 


\section{Conclusions}

Distributive trade (retail and wholesale) is an influential economic sector in the European Union nations. This is shown in numerous European Commission documents which, in late years, more and more focus on distributive trade sector, particularly retail. They speak about beefing up the competitiveness of retail and distributive trade sector as a driver of growth, competitiveness, and exercise, as considerably as the significance of distributive trade sector to accomplish the goals of the European Union strategy by 2020. At the same time, economic growth, as a macroeconomic phenomenon, is one of economic policy goals. In this respect, economic policy focuses on those sectors that generate higher growth rates. For instance, until the 1960s, the industry sector was in the focus of economic policy in many rural areas, succeeded by a gradual orientation towards the service sector. Exploring the relationship between the service sector and economic development is characteristic of a great number of papers published in the past 10-20 years. What is observed is that few of those studies links distributive trade and economic development. These works primarily focus on the impact of distributive trade sector on productivity and use of single or several nations. These facts have been the inspiration for the research carried out in this report.

Taking into account this fact, the work tested the theory that the development of economic activities in the distributive trade sector generated higher real economic growth rates in the 28 nations of the European Union in the period from 2008 to 2015. The constructed multiple regression model clearly shows that, with ceteris paribus clause, in the selected group of nations in the analyzed period, increase of turnover per employee of $10 €$ in the distributive trade sector in one year affected the intensification of real economic growth rate by 0.15 percent in the same year. The constructed multiple regression model has taken into account the impact of the fiscal crisis, and expressed that it bore a negative impact on the real GDP growth pace. The model also took into account the specificity of each of the surveyed countries, as a causal factor of the actual economic growth rate, which was corroborated by the adequate statistical test.

The limitation of this work is reflected in the fact that the answers are valid for the observed countries and merely for the observed time interval, with the clause ceteris paribus, which is very restrictive in economic inquiry. However, the solutions obtained are a good starting level for the time horizon of reflection to be enlarged and the number of control variables increased. This is because, apart from the importance and significance of the distributive trade sector for economic growth, this research also points to the negative impact of final consumption expenditure of general government on real economic development. In other words, over a broader time horizon, the optimal degree of final consumption expenditure of general government should be found, which would, on the unitary hand, contribute to greater economic activity in the distributive trade sector, while at the same time not compromising economic growth. The optimal point of government spending is particularly important whenever there is increasing criticism in the nations of the European Union at the expense of internal (fiscal) imbalance. It is increasingly argued that the next wave of the global economic crisis will be induced by excessive fiscal deficits in the EU states. At the same time, distributive trade sector, no matter how significantly, it affects the positive economic growth rates, is most exposed to the economic crisis, and accordingly, based on the Keynes 
principle of accelerating, will further reduce the future economic growth. All these events can be the subject of new economic research, because we have shown here that distributive trade sector in the EU countries has an important impact on economic growth.

\section{References}

Aghion, P. \& Howitt, P. (1998). Endogenous growth theory. Cambridge: MIT Press.

Aldashev, G., \& Zanarone, G. (2017). Endogenous enforcement institutions. Journal of Development Economics, 128, 49-64. https://doi.org/10.1016/j.jdeveco.2017.05.002

Balios, D., Eriotis, N., Fragoudaki, A., \& Giokas, D. (2015). Economic efficiency of Greek retail SMEs in a period of high fluctuations in economic activity: a DEA approach. Applied Economics, 47(33), 3577-3593. https://doi.org/10.1080/00036846.2015.1019033

Battisti, M., Del Gatto, M., \& Parmeter, C. F. (2018). Labor productivity growth: disentangling technology and capital accumulation. Journal of Economic Growth, 23(1), 111-143.

https://doi.org/10.1007/s10887-017-9143-1

Benazić, M. (2014). Determinants of retail trade in Croatia. Economic Research, 27(1), 607-628. https://doi.org/10.1080/1331677X.2014.967538

Berman, B. (2006). Marketing channels. New York: John Wiley \& Sons.

Beyers, W. B. (2005). Services and the changing economic base of regions in the United States. Service Industries Journal, 25(4), 461-476. https://doi.org/10.1080/02642060500092113

Blackaby, F. (1978). Deindustrialisation. London: Heinemann.

Borcan, O., Olsson, O., \& Putterman, L. (2018). State history and economic development: evidence from six millennia. Journal of Economic Growth, 23(1), 1-40. https://doi.org/10.1007/s10887-017-9152-0

Bryson, J. R., Daniels, P. W., \& Warf, B. (2004). Service worlds-People, organizations, technologies. London: Routledge.

Capello, R., \& Fratesi, U. (2013). The service sector in the new globalization phase: Evidence from European regions. In J. R. Cuadrado-Roura (Ed.), Service industries and regions: Growth, location and regional effects (pp. 43-64). Heidelberg: Springer Berlin Heidelberg. https://doi.org/10.1007/978-3-642-35801-2_3

Cinnirella, F., \& Streb, J. (2017). The role of human capital and innovation in economic development: evidence from post-Malthusian Prussia. Journal of Economic Growth, 22(2), 193-227. https://doi.org/10.1007/s10887-017-9141-3

Clemes, M. D., Hu, B., \& Li, X. (2016). Services and economic growth in China: an empirical analysis. Journal of the Asia Pacific Economy, 21(4), 612-627. https://doi.org/10.1080/13547860.2016.1190492

Cuadrado-Roura, J. R. (2013). The location of service industries. In J. R. Cuadrado-Roura (Ed.), Service industries and regions: Growth, location and regional effects (pp. 253-284). Berlin: Springer Berlin Heidelberg. https://doi.org/10.1007/978-3-642-35801-2

Cvetanović, S., \& Despotović, D. (2014). Znanje kao komponenta ljudskogkapitala u modelima ekonomskog rasta. Škola biznisa, 1, 1-17 (in Serbian).

Cvetanović, S., \& Mladenović, I. (2015). Ekonomija kapitala i finansiranje razvoja [Economy of capital and financing of development]. Niš: autorovo izdanje.

Cvetanović, S., Filipović, M., \& Dragutinović, D. (2015). Teorija privrednog rasta i razvoja [Theory of economic growth and development]. Beograd: Ekonomski fakultet Univerziteta u Beogradu.

Daniels, P. W., \& Bryson, J. R. (2005). Sustaining business and professional services in a second city region. The Service Industries Journal, 25(4), 505-524. https://doi.org/10.1080/02642060500092220 
Delogu, M., Docquier, F., \& Machado, J. J. (2018). Globalizing labor and the world economy: the role of human capital. Journal of Economic Growth, 23(2), 223-258.

https://doi.org/10.1007/s10887-017-9153-z

Di Berardino, C., D’Ingiullo, C., \& Sarra, A. (2017). Distributive trade and regional productivity growth. The Service Industries Journal, 37(13-14), 833-857. https://doi.org/10.1080/02642069.2017.1359261

Dibb, S., Simkin, L., Pride, W. M., \& Ferrell, O. C. (1991). Marketing. Zagreb: Mate d.o.o.

European Commision. (2013). Implementation of the European Retail Action Plan. Retrieved from https:// http://europa.eu/rapid/press-release_IP-13-78_en.htm

European Commision. (2018). A European retail sector fit for the 21st century. Communication from the Commission to the European Parliament, the Council, the European Economic and Social Committee and the Committee of the Regions. Retrieved from https://ec.europa.eu/growth/content/european-retail-sector-fit-21st-century_en

Eurostat. (2008). Statistical classification of economic activites in the European Community. Retrieved from http://ec.europa.eu/eurostat/documents/3859598/5902521/KS-RA-07-015-EN.PDF

Eurostat. (2018). Retail trade volume index overview. Retrieved from http://ec.europa.eu/eurostat/ statistics-explained/index.php/Retail_trade_volume_index_overview\#Retail_trade_developments

Garcilazo, E., Mouradian, F., \& Oliveira-Martins, J. (2013). Patterns and trends in services related activities in OECD regions. In J. R. Cuadrado-Roura (Ed.), Service industries and regions: Growth, location and regional effects (pp. 65-108). Heidelberg: Springer Berlin Heidelberg. https://doi.org/10.1007/978-3-642-35801-2_4

Ghavidel, S., \& Sheshkalany, A. N. (2017). Cost disease in service sector. The Service Industries Journal. 37(3-4), 206-228. https://doi.org/10.1080/02642069.2017.1306056

Grossman, G., \& Helpman, E. (1994). Endogenous innovation in the theory of growth. Journal of Economic Perspectives, 8(1), 23- 44. https://doi.org/10.1257/jep.8.1.23

Hendrik, V. B., \& Lewer, J. J. (2007). International trade and economic growth. New York: Routledge.

Kedir, A. M., Williams, C., \& Altinay, L. (2018). Services industries and the informal economy: an introduction. The Service Industries Journal, 38(11-12), 645-649. https://doi.org/10.1080/02642069.2018.1486959

Khayum, M. F. (1995). The impact of service sector growth on intersectoral linkages in the United States. The Service Industries Journal, 15(1), 35-49. https://doi.org/10.1080/02642069500000003

Kornai, J. (1992). The socialist system, the political economy of communism. New Jersey: Princeton University Press. https://doi.org/10.1093/0198287763.001.0001

Kotler, P., Keller, K. L., \& Martinović, M. (2014). Upravljanje marketingom. Zagreb: Mate d.o.o.

Levy, M., Weitz, B. A., \& Grewal, D. (2014). Retailing management. New York: McGraw-Hill.

Ling, S. L. M. (2013). Increasing productivity of distributive trade through retail innovations: evidence from Malaysia. The International Review of Retail, Distribution and Consumer Research, 23(3), 324-352. https://doi.org/10.1080/09593969.2013.764338

Lovreta, S., Radunović, D., \& Petković, G. (1998). Trgovina-Teorija i praksa [Distributive trade - Theory and practise]. Beograd: Savremena administracija.

Lundquist, K.-J., Olander, L.-O., \& Henning, M. S. (2008). Producer services: growth and roles in longterm economic development. The Service Industries Journal, 28(4), 463-477. https://doi.org/10.1080/02642060801917588

Lundquist, K.-J., Olander, L.-O., \& Henning, M. S. (2005). Renewal and obsolescence. An evolutionary perspective on industry growth and regional development in Sweden 1978-2002 (Rapporter och Notiser 166). Lund, Sweden: Lund University, Department of Social and Economic Geography. 
Lundquist, K.-J., Olander, L.-O., \& Henning, M. S. (2006). Producer services. Boosters or followers? An evolutionary approach to producer services and technology shifts in time and space (Rapporter och Notiser 167). Lund, Sweden: Lund University, Department of Social and Economic Geography.

Moreno, J. D. J., \& Carrasco, O. R. (2015). Evolution of efficiency and its determinants in the retail sector in Spain: new evidence. Journal of Business Economics and Management, 16(1), 244-260. https://doi.org/10.3846/16111699.2012.732958

Olsen, J., \& Granzin, K. (1990). Economic development and Channel Structure-Multinational Study. Journal of Makromarketing, 1, 61-74. https://doi.org/10.1177/027614679001000205

Ozak, O. (2018). Distance to the pre-industrial technological frontier and economic development. Journal of Economic Growth, 23(2), 175-221. https://doi.org/10.1007/s10887-018-9154-6

Rocha, I. L. (2018). Manufacturing as driver of economic growth. PSL Quarterly Review, 71(285), 103138. https://doi.org/10.2139/ssrn.3211881

Rodrik, D. (2007). One economics, many recipes: globalization, institutions, and economic growth. New Jersey: Princeton University Press.

Romer, P. (1989). Endogenous technological change (NBER Working Paper No. 3210).

Romer, P. (1990). Endogenous technological change. Journal of Political Economy, 98(5), 71-102. https://doi.org/10.1086/261725

Ruhiiga, T.M. (2011). The wholesale-retail sector and changes in consumer market response in rural South Africa. Journal of Social Sciences, 29(1), 91-99. https://doi.org/10.1080/09718923.2011.11892959

Samuelson, P., \& Nordhaus, W. (2008). Ekonomija [Economy]. Beograd: Mate.

Schmidheiny, K. (2015). Short guides to microeconometrics, panel data: Fixed and random effects. Basel: Unversität Basel.

Schneider, P. H. (2005). International trade, economic growth and intellectual property rights: A panel data study of developed and developing countries. Journal of Development Economics, 78(2), 529547. https://doi.org/10.1016/j.jdeveco.2004.09.001

Scully, G. (1988). The institutional framework and economic development. Journal of Political Economy, 96(3), 652-662. https://doi.org/10.1086/261555

Warland, M., \& Mayer, H. (2017). Peculiarities of public sector clients in service innovations. The Service Industries Journal, 37(2), 105-124. https://doi.org/10.1080/02642069.2017.1297427

Williams, C. C., \& Horodnic, I. A. (2018). Extent and distribution of unregistered employment in the service industries in Europe. The Service Industries Journal, 38(11-12), 856-874. https://doi.org/10.1080/02642069.2018.1481209

Williams, C. C. (1997). Rethinking the role of the retail sector in economic development. The Service Industries Journal, 17(2), 205-220. https://doi.org/10.1080/02642069700000011 